\title{
Lithotrophic Bacterial Leaching of Heavy Metals from Sediments Dredged from the Deûle Canal, France
}

\author{
N.Y. Sabra ${ }^{1}$, H.C. Dubourguier ${ }^{2}$, A. Benmimouna ${ }^{2}$, M.N. Duval' ${ }^{2}$, S. Camuzeaux ${ }^{2}$ and T. Hamieh ${ }^{* 1,3}$ \\ ${ }^{I}$ Faculty of Agricultural Engineering and Veterinary Medicine, Dekwaneh, Beirut, Lebanese University, Lebanon \\ ${ }^{2}$ Institut Supérieur d'Agriculture de Lille, 59046, Lille Cedex, France \\ ${ }^{3}$ Laboratory of Materials, Catalysis, Environment and Analytical Methods (MCEMA-CHAMSI) Faculty of Sciences, \\ Lebanese University, Hariri Campus, Hadath, Beirut, Lebanon
}

\begin{abstract}
Lithotrophic bacterial leaching of heavy metals from dredged sediments was studied in semi-pilot scale air-lift bioreactors. Prior to the bioleaching experiments, a physico-chemical characterization of the sediments comprising a sequential extraction study was conducted. The sediments turned out to be highly loaded with heavy metals, and with the exception of managanese, mainly associated to the oxidizable fraction of the sediments and thus strongly linked to the latter. The heavy metals could be classified by decreasing order of mobility as follows: $\mathrm{Mn}>\mathrm{Zn}>\mathrm{Cu}>\mathrm{Cd}>\mathrm{Pb}$.

The bacterial leaching was found to be strongly dependent on the nature of the mineral substrate. Sulfur gave the best solubilization results in comparison with reduced iron or with a combination of reduced iron and sulfur. In the presence of oxygen, lithotrophic bacteria oxidized sulfur into sulfates and induced an acidification of the sediments. These conditions led to the release of the metals that were tightly linked to the sediments, that is those associated with the sulfides and/or with the organic matter. With sulfur as a substrate, the solubilization percentages varied within 30 days between 72 and 93\% of the total sediment content (wt/wt) for cadmium, copper, manganese and zinc. Much lower biosolubilization percentages were obtained in the case of lead because of the poor solubility of lead sulfate.
\end{abstract}

Keywords: Sediments, heavy metals, remediation, chemical speciation, sulfur, iron, bioleaching, Thiobacillus spp.

\section{INTRODUCTION}

The Nord-Pas de Calais region in France suffers from an important pollution of its water streams as a result of its extensive past industrial activities. The region counts $600 \mathrm{~km}$ of water channels and these are mainly contaminated with heavy metals [1]. Given its plane topography, large volumes of sediments are formed every year. These sediments have to be dredged periodically in order to prevent floods and navigation problems. The volumes of dredged sediments between 1990 and 2000 is estimated to 1.7 million $\mathrm{m}^{3}$. Seventy percent of the dredged and analyzed sedimenst were polluted with various pollutants including heavy metals [2].

Confined disposal or landfilling and incineration are widely used for the treatment of contaminated sediments [3]. The first technique does not treat polution and is limited by the availability of disposal spaces and the risk of ground water pollution due to a potenial corrosion of the isolating membranes with time. The second is limited by its elevated cost. Both do not allow the valorization of the sediments after treatment. Other techniques such as vitrification are still at a limited developmental stage and are expensive. On the other hand, the practical experience in the application of solification/stabilization to sediments is still low although its

*Address correspondence to this author at the Faculty of Agricultural Engineering and Veterinary Medicine, Dekwaneh, Beirut, Lebanese University, Lebanon; Tel: +961.1.495.786, +961.3.968.850; Fax: +961.1.510.870; E-mail: tayssir.hamieh@ul.edu.lb cost is moderate [3]. Also, this technology does not offer a safe guarantee against the remobilization of heavy metals from the sediments in case their physico-chemical conditions change such as $\mathrm{pH}$.

The classical technologies such as landfilling and incineration may be substituted by bioremediation $[4,5]$. Biological treatment methods are the methods of choice because they are natural, economically attractive and because they allow the reuse of the sediments after their treatment.

Lithotrophic bacterial leaching of heavy metals is an interesting biological treatment method. It is based on the activity of chemolithotrophic bacteria to oxidize poorly soluble metal sulfides into water soluble metal sulfates. The oxidation mechanisms can be either direct necessitating an intimate contact between the bacteria and the metal sulfides or indirect, i.e mediated by ferric ions resulting from the bacterial oxidation of reduced iron compounds [6-8]. In both cases, sulfuric acid is produced and lowers the $\mathrm{pH}$ and contributes significantly in the solubilization of heavy metals [9]. The mostly known leaching bacteria belong to the genus Thiobacillus sp., namely Thiobacillus ferrooxidans and Thiobacillus thiooxidans [6, 7]. These bacteria were first used in biohydrometallurgy to extract metals from solid substrates like low grade ores $[10,11]$. Later on, biohydrometallurgical decontamination technology has been extensively applied to waste water sewage sludges $[5,12,9$, 13]. Less work has however been done on more complex matrices like sediments. [14] tested Fe based submerged 
leaching and solubilized more than $60 \% \mathrm{Cu}$ and $\mathrm{Zn}$ and $\mathrm{Mn}$. [15] tested the effect of an additional substrate, sulfur, in large scale percolation leaching tests. The study was limited by mass transfer and led, on average, to $62 \%$ of metal solubilization. As with the work of [14], the experiment required an initial acidification of the sediments. Apart from increasing treatment costs, pre-acidifying the sediments is an undesirable phenomenon because it results in excessive foaming and in the production of $\mathrm{CO}_{2}$ and the toxic $\mathrm{H}_{2} \mathrm{~S}$ gas upon the reaction of the added minreal acids with the carbonates and sulfides present in the sediments matrix.

Better bioleaching yields were obtained by [4] when using sulfur as substrate and operating in air lift bioreactors without initial sediments preacification.

The objective of this paper is to elaborate further the research work done on sediments so far. It aims at testing and comparing the effect of various substrates (iron, sulfur and a mixture of iron and sulfur) on the bioleaching of heavy metals from contaminated sediments. Such comparison would be done under optimal aeration condition in air-lift bioreactors and without an initial preacidification of the sediments.

Before conducting the bioleaching studies, a physicochemical characterization was carried out in order to determine the level of contamination of the sediments as well as the speciation of the metals. The latter was studied chemically by conducting a sequential extraction study. We have chosen the extraction scheme proposed by the European Measurements and Testing Program (previously known as the Community Bureau of Reference CBR). This scheme is in fact representative of most of the existing extraction schemes and has been validated by several interlaboratory comparisons and by certified reference materials [16]. Parallel to bioleaching experiments, microbiological studies were carried out in order to identify the bacterial strains that were responsible for the solubilization of the heavy metals.

\section{MATERIALS AND METHODS}

\section{Physico-Chemical Characterization of the Sediments}

\section{Analysis of Sediments}

The sediments were sampled from the Deûle canal situated in the Nord-Pas de Calais region in northern France. Sampling was done from the point 080000 of the canal using a Van Veen dredge of $5 \mathrm{~L}$ capacity. This point is localized in the village of Haubourdin which is situated at the south of the city of Lille, the capital of northern France (Fig. 1).

The sediments were digested and then analyzed for their total heavy metal contents by inductively coupled plasma optical emission spectrometry (ICP-OES). For the digestion, $0.5 \mathrm{~g}$ of dry sediment were digested in $10 \mathrm{ml}$ of concentrated nitric acid for 10 minutes in a microwave apparatus according to the EPA method 3051 [17]. The temperature of the samples should rise to $175^{\circ} \mathrm{C}$ in less than 5.5 minutes and remain between $170-180^{\circ} \mathrm{C}$ for 10 minutes and pressure must not exceed 6 atmospheres.

Organic matter and dry suspended matter (SM) contents were determined by centrifuging the samples at $8065 \mathrm{rpm}$ for 25 minutes, heating the solid residue to $550^{\circ} \mathrm{C}$ for 4 hours and $105^{\circ} \mathrm{C}$ for 2 hours respectively and expressing the resulting dry weights as a function of the $105^{\circ} \mathrm{C}$ and fresh sample weights respectively.

\section{Sequential Extraction of Heavy Metals from Sediments}

The sequential extraction study was carried out according to [16] which adopted the protocol of the Measurements and Testing Progamme of the Euperan Union that was previously known as Community Bureau of Reference (CBR). The sediments were air dried then sieved to $90 \mu \mathrm{m}$ prior to extraction as per the procotol of [16]. The extraction comprised three main steps:

-Step 1: $1 \mathrm{~g}$ of dry sediment was placed in a centrifuge tube and $40 \mathrm{ml}$ of $0.11 \mathrm{M}$ acetic acid were added. The mixture was shaken for 16 hours (overnight) at ambient temperature $\left(25^{\circ} \mathrm{C}\right)$ using a horizontal shaking table. The sediments were continually in suspension during the extraction. At the end of the extraction period, the mixture was centrifuged and the supernatent (extract) was filtered through a $0.45 \mu \mathrm{m}$ membrane then analyzed for heavy metals by ICP.

- Step 2: the solid residue from step 1 was rinsed with distilled water. The rinsing water was discarded to avoid reagents interaction and the residue and then extracted for 16 hours (overnight) using the same shaking table with $40 \mathrm{ml}$ of freshly prepared $0.1 \mathrm{M}$ hydroxylamine hydrodrochloride that were acidified with nitric acid to $\mathrm{pH} 2$. At the end of the extraction, the mixture was centrifuged as in step 1 and the supernatent (extract) was filtered through a $0.45 \mu \mathrm{m}$ membrane then analyzed for heavy metals.

- Step 3: the solid residue from step 3 was rinsed with distilled water. The rinsing water was discarded and the residue was then digested for 1 hour with $10 \mathrm{ml}$ of $30 \%$ $\mathrm{H}_{2} \mathrm{O}_{2}$ that were adjusted to $\mathrm{pH}$ 2-3 with nitric acid. Digestion took place in the centrifuge tube after covering it with a watch glass. Digestion was continued for an additional hour but at $85^{\circ} \mathrm{C}$. Next, the watch glass was removed and heating of the residue was continued until its volume was reduced to few $\mathrm{ml}$ only. $10 \mathrm{ml}$ of the $\mathrm{H}_{2} \mathrm{O}_{2}$ solution were then added and the same digestion $\left(85^{\circ} \mathrm{C}\right.$, 1hour) and volume reduction procedure was repeated. Finally, $50 \mathrm{ml}$ of a $1 \mathrm{M}$ ammonium acetate solution which was adjusted to $\mathrm{pH} 2$ with acetic acid was added to the residue and the latter was extracted with the ammonium acetate solution for 16 hours (overnight) using the horizontal shaking table. The mixture was centrifuged and the supernatent (extract) was filtered through a $0.45 \mu \mathrm{m}$ membrane then analyzed for heavy metals.

The above CBR sequential extraction scheme yields 4 major fractions which represent the main types of interactions that exist between the heavy metals and the sediments $[16,18]$. In a decreasing order of metal mobility, we distinguish:

- The acid-soluble fraction or step 1 extract: it comprises exchangeable and carbonate bound heavy metals. Their mobilization is governed by acid-base equilibria,

- The reducible fraction or step 2 extract: it comprises heavy metals bound to the $\mathrm{Fe}$ and $\mathrm{Mn}$ oxides and hydroxides. Their mobilization occurs under reducing conditions, 


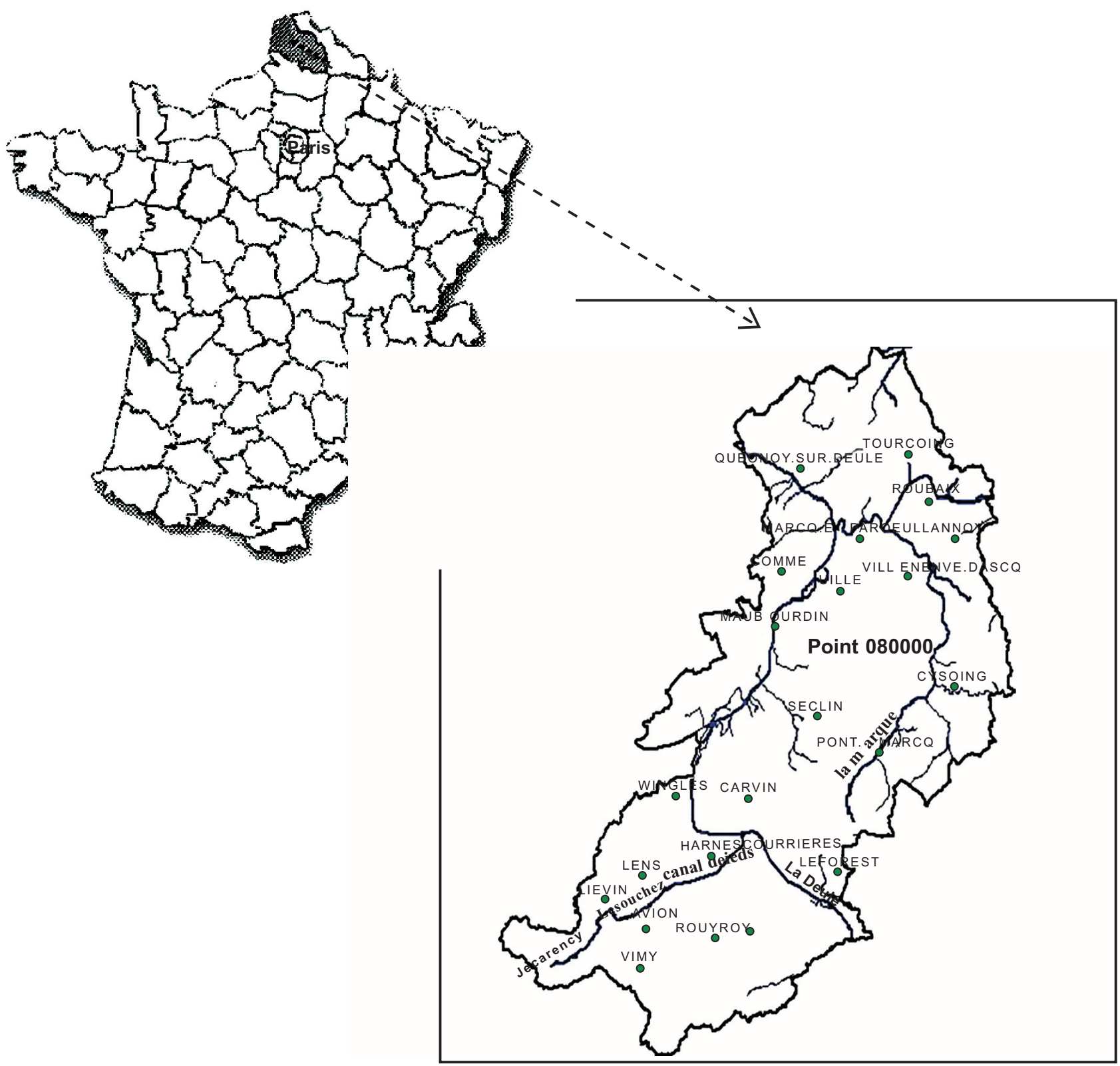

Fig. (1). The 080000 sampling point in the Deûle canal, Haubourdin city, Nord-Pas de Calais region, France.

- The oxidizable fraction or step 3 extract: it comprises heavy metals that are bound to sulfides and to the organic matter. Their mobilization occurs under strong oxidizing conditions,

- The residual fraction: it comprises heavy metals that are strongly bound to the crystalline lattice of the sediments and which cannot be released by the reagents used in the previous steps.

\section{Bacterial Enrichments}

Prior to the bioleaching studies, enrichment experiments were conducted in order to develop the activity of the sediments iron and sulfur indigenous lithotrophic bacteria. For the sulfur treatment, one liter beakers were filled with sediments at a concentration of $20 \mathrm{~g}$ of dry matter $/ \mathrm{kg}$ of fresh sediments. They were supplemented with $10 \mathrm{~g}$ of thyndalised sulfur $/ \mathrm{kg}, 4 \mathrm{~g} \mathrm{~kg}^{-1}$ of $\mathrm{KH}_{2} \mathrm{PO}_{4}$ and $0.49 \mathrm{~g} \mathrm{~kg}^{-1}$ of $\left(\mathrm{NH}_{4}\right)_{2} \mathrm{SO}_{4}$. Sulfur thyndalisation was carried out by heating sulfur powder in water for $30 \mathrm{mn} /$ day at $100^{\circ} \mathrm{C}$ during three consecutive days. No $\mathrm{pH}$ adjustment was done to the sediments. They were mechanically agitated at $150 \mathrm{rpm}$ at ambient temperature. A progressive $\mathrm{pH}$ drop was observed with time. When the $\mathrm{pH}$ became less or equal to 2 , the sediments were used to inoculate new fresh sediments at a rate of $5 \%(\mathrm{w} / \mathrm{w})$. The operation was repeated until the $\mathrm{pH}$ drop became rapid and optimized over two successive inoculations. The activity of the sediments natural sulfur bacteria was then considered as well developed. For the iron 
bacteria enrichment technique, the same procedure was followed except that the sediments were supplemented with $10 \mathrm{~g} \mathrm{~kg}^{-1}$ of $\mathrm{FeSO}_{4}, 0.5 \mathrm{~g} \mathrm{~kg}^{-1} \mathrm{KH}_{2} \mathrm{PO}_{4}$ and $4.21 \mathrm{~g} \mathrm{~kg}^{-1}$ $\mathrm{NH}_{4} \mathrm{NO}_{3}$. The $\mathrm{pH}$ was adjusted to 4 as the iron bacteria are acidophilic and the sediments were agitated at $120 \mathrm{rpm}$ at ambient temperature.

\section{Bioleaching Expriments}

\section{Air-Lift Bioreactors}

The semi-pilot scale bioleaching experiments were conducted under non sterile conditions in 45 liters air-lift bioreactors (Fig. 2). The reactors were constructed by CME Company (France). They were made of stainless steel and were internal loop airlift bioreactors $1.3 \mathrm{~m}$ long and $30 \mathrm{~cm}$ wide. Each reactor comprised an inner central cylinder (internal diameter $=13.3 \mathrm{~cm}$ ) or riser and an inverted conical opening covered with Plexiglas. Compressed air was injected at the bottom of the riser leading to an upward flow of the sediments in the riser and to their downward movement in the side cylinders or downcomers and thus resulting in the continuous circulation of the sediments. Each reactor was equipped with temperature, dissolved oxygen and $\mathrm{pH}$ electrodes as well as with pressure sensors.

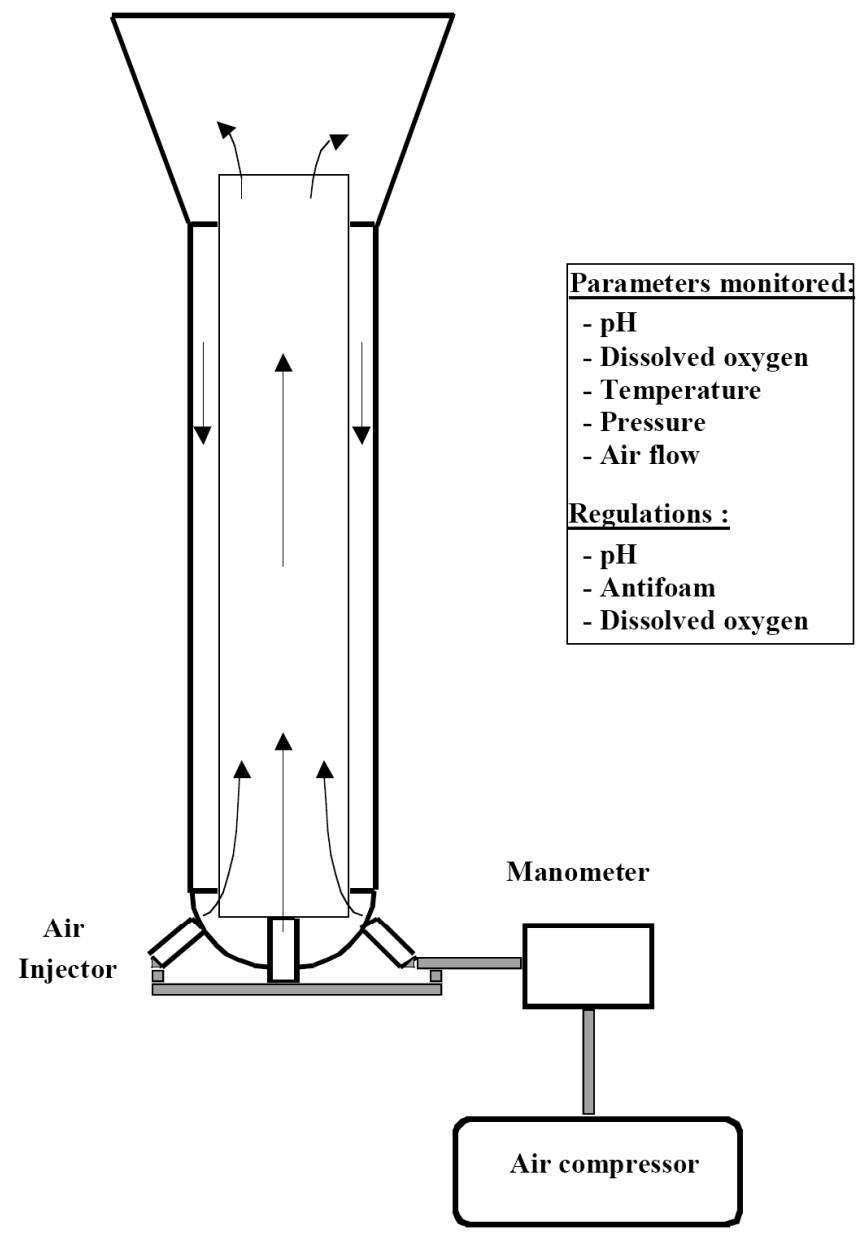

Fig. (2). Air Lift bioreactor used in metal bioleaching experiments (constructor: CME, France).

\section{Treatments Tested}

Three types of treatments were tested: an iron treatment, an iron and sulfur treatment and a sulfur treatment (Table 1).
The inocula consisted of enrichment cultures based on the substrate(s) used in the different treatments. The $\mathrm{Fe} / \mathrm{S}$ treatment received, on fresh weight basis, $5 \%$ of the iron enrichment and $5 \%(\mathrm{w} / \mathrm{w})$ of the sulfur enrichment.

Table 1. Working Conditions in the $\mathrm{Fe}, \mathrm{Fe} / \mathrm{S}$ and $\mathrm{S}$ Treatments

\begin{tabular}{|c|c|c|c|}
\hline & $\mathbf{F e}$ & $\mathbf{F e} / \mathbf{S}$ & $\mathbf{S}$ \\
\hline \hline $\mathrm{S}\left(\mathrm{g} \mathrm{kg}^{-1}\right)$ & - & 5 & 10 \\
\hline $\mathrm{FeSO} 4.7 \mathrm{H}_{2} \mathrm{O}\left(\mathrm{g} \mathrm{kg}^{-1}\right)$ & 10 & 5 & - \\
\hline$(\mathrm{NH} 4)_{2} \mathrm{SO}_{4}\left(\mathrm{~g} \mathrm{~kg}^{-1}\right)$ & 3 & 2,5 & 0,5 \\
\hline $\mathrm{KH}_{2} \mathrm{PO}_{4}\left(\mathrm{~g} \mathrm{~kg}^{-1}\right)$ & 0,5 & 2 & 4 \\
\hline $\mathrm{K}_{2} \mathrm{HPO}_{4}\left(\mathrm{~g} \mathrm{~kg}^{-1}\right)$ & - & - & 4 \\
\hline $\mathrm{MS}\left(\mathrm{g} \mathrm{kg}^{-1}\right)$ & 26 & 31 & 31 \\
\hline Inoculation $\%(\mathrm{~m} / \mathrm{m})$ & $10 \%$ & $10 \%$ & $10 \%$ \\
\hline Initial pH & Non adjusted & Non adjusted & Non adjusted \\
\hline
\end{tabular}

\section{Analytical Follow-Up}

The $\mathrm{pH}$ and the dissolved oxygen concentration were taken on daily basis. Dissolved oxygen was measured using oxygen probes introduced inside the bioreactor. At the end of each week of treatment, microbiological counts were conducted in duplicates on the following media:

- General nutritive agar (GN): a general microbial medium (Diagnostic Pasteur, France);

- Neutral $0.5 \%$ thiosulfate agar (NT): a selective medium for mildly acidophilic lithotrophic bacteria [19].

A microbiological identification study was carried out on the bacteria that were isolated from the petri dishes used for counting of the microbial population, namely from NT petri dishes. The isolated strains were subjected to the following tests:

- Preliminary tests: fresh state observation, mobility test, gram stain, oxidase, catalase, respiratory pathway. Apart from the fresh state observation which has been done under the microscope, these physiological tests have been carried out using the physiological gallery API 20 NE manufactured by BioMerieux.

- Metabolism of specific substrates: glucose [20, 21], $\mathrm{KNO}_{3}[20,21]$, sulfur [22, 20, 19] and Fe (II) [21].

- $\mathrm{pH}$ lowering capacity on thiosulfate and sulfur neutral liquid media $[22,19]$.

For the bioleaching experiments, samples were collected every two days. They were centrifuged at $8065 \mathrm{rpm}$ for 25 $\mathrm{mn}$ at $10^{\circ} \mathrm{C}$. Both the supernatant and the solid residue were stored at $-20^{\circ} \mathrm{C}$ before analysis.

The supernatants were analyzed for their heavy metals concentrations by ICP-OES and for their sulfate content according to the French standard method NFT 90-040 [23].

The solid residues were analyzed for their heavy metals and suspended dry matter content as described previously. 


\section{RESULTS AND DISCUSSION}

\section{Sediments Characterization}

According to Table 2, the sediments have a fine texture as the particles having less than $50 \mu \mathrm{m}$ in diameter represent more than $50 \%$ of the dry suspended matter (SM) weight. The sediments are also rich in organic matter as the organic matter percentage is greater than the mean values $(2-10 \%)$ found in the sediments of the Nord Pas de Calais region [24].

To assess the level of contamination and in the absence of French standards specific for sediments, the total concentrations of heavy metal were compared to the French soil standards, which are values above which, no sediment or sludge application is allowed on a given soil. The sediments were not polluted by $\mathrm{Cr}$ as its concentration was below the soil standard. The contamination of the sediments was slight in the case of $\mathrm{Cu}$ but high in the case of $\mathrm{Pb}, \mathrm{Zn}$ and $\mathrm{Cd}$. Although no legislation exists at the present time for $\mathrm{Mn}$, we can notice the high load of the sediments in this metal as its concentration is superior to the Natural Values, which are values below which a given soil is considered as not polluted.

\section{Sequential Extraction Study}

The sequential extraction study (Fig. 3) revealed that most of the studied metals $(\mathrm{Cu}, \mathrm{Pb}$ and $\mathrm{Cd})$ are tightly linked to the matrix as they are mainly associated with the sulfides and with the organic matter fraction. $\mathrm{Zn}$ and especially $\mathrm{Mn}$ are more mobile than the rest of the metals because of their association with the acid-soluble and reducible fractions of the sediments. The heavy metals can be ranked according to a decreasing mobility order as follows: $\mathrm{Mn}>\mathrm{Zn}>\mathrm{Cd}>\mathrm{Cu}>$ $\mathrm{Pb}$. The predominance of the metals in the oxidizable fraction could be due to the importance of the heavy metal load. The lower the latter, that is the lower the pollution of the sediments, the greater is the tendency to have increased residual metal concentrations $[25,26]$. The residual fraction reflects thus the natural geochemical background of the sediment. Besides the importance of the heavy metal load, the predominance of metals in the oxidizable fraction could be explained by the age of the pollution with more metals in the oxidizable fraction when the pollution is old. Another reason would be that organic matter and Fe-oxides are more accessible to heavy metals than other sediment phases [27, 28]. Also, metals might have been redistributed from mobile fractions (acid soluble and the reducible fractions) towards the sufides and organic matter in oxidizable fraction. Such migration may be caused by the establishment in the river of conditions that mobilize metals like slight acidification. Finaly, this migration can also be due to the sequential extraction procedure itself [18] observed a redistribution of lead and copper as a function of humic acids and kaolinite in artificial sediments. This observation needs however to be validated on real sediment samples.

Our findings are close to results found by other researchers. The predominant association of $\mathrm{Cu}$ with the organic matter fraction and of $\mathrm{Zn}$ with the reducible fraction have been observed [27-30]. On the other hand, the concentration of $\mathrm{Pb}$ in the oxidizable fraction has been recorded by [31] (Mester et al., 1998, ref 31). Close findings were also reported by [27], who found that the acid volatile sulfides have the priority to bind to heavy metals followed by organic matter and carbonates.

\section{Bioleaching Experiments}

\section{pH Evolution}

According to Fig. (4), the Fe treatment was the longest treatment. A latency period is observed during the first week. It corresponds most probably to the development of the inoculum and to the adaptation of the sediments microbial population to the substrate added. After this latency period, the $\mathrm{pH}$ begins to drop. The acidification of the sediments is however limited as the $\mathrm{pH}$ remains near 6 . A certain $\mathrm{pH}$ stabilization is thus set up and remains observed even if sulfur is added to the sediments at day 64. Fe oxidizing bacteria like Thiobacillus ferrooxidans require an initial preacidification of the medium of $\mathrm{pH}$ less than 4.0 in order to leach heavy metals from contaminated matrices [32]. Also, Thiobacillus ferrooxidans oxidize sulfur slowly compared to Thiobacillus Thiooxidans [33]. Thus, in the Fe reatment, the low $\mathrm{pH}$ drop even after sulfur addition is most probably linked to the poor activity of the Fe oxidizing bacteria in the

Table 2. Characteristics of the Sediments Dredged from the Deûle canal in the Haubourdin Region at the Point 080000

\begin{tabular}{|c|c|c|c|c|}
\hline Parameters & French Soil Standards ${ }^{A}$ & French Sludge Standards ${ }^{\alpha}$ & Natural Values & Results \\
\hline \% $\% \mathrm{SM}^{\beta}$ (with respect to fresh sediment weight) & NA & NA & NA & 21.3 \\
\hline$\%$ organic matter (with respect to $\% \mathrm{SM}$ ) & NA & NA & NA & 14.02 \\
\hline Iron (mg kg-1 of SM) & NA & NA & 10000 & 24225 \\
\hline Copper (mg kg ${ }^{-1}$ of SM) & 100 & 1000 & 20 & 145 \\
\hline Zinc (mg kg ${ }^{-1}$ of SM) & 300 & 3000 & 75 & 6014 \\
\hline Lead (mg kg ${ }^{-1}$ of SM) & 100 & 800 & 20 & 1222 \\
\hline Chromium (mg kg ${ }^{-1}$ of SM) & 150 & 1000 & 25 & 130 \\
\hline
\end{tabular}

${ }^{a}$ French standards as given by the decision of January $8^{\text {th }} 1998$ that figures in the French Official Journal (1998).

${ }^{\beta} \mathrm{SM}$ : Suspended matter. 


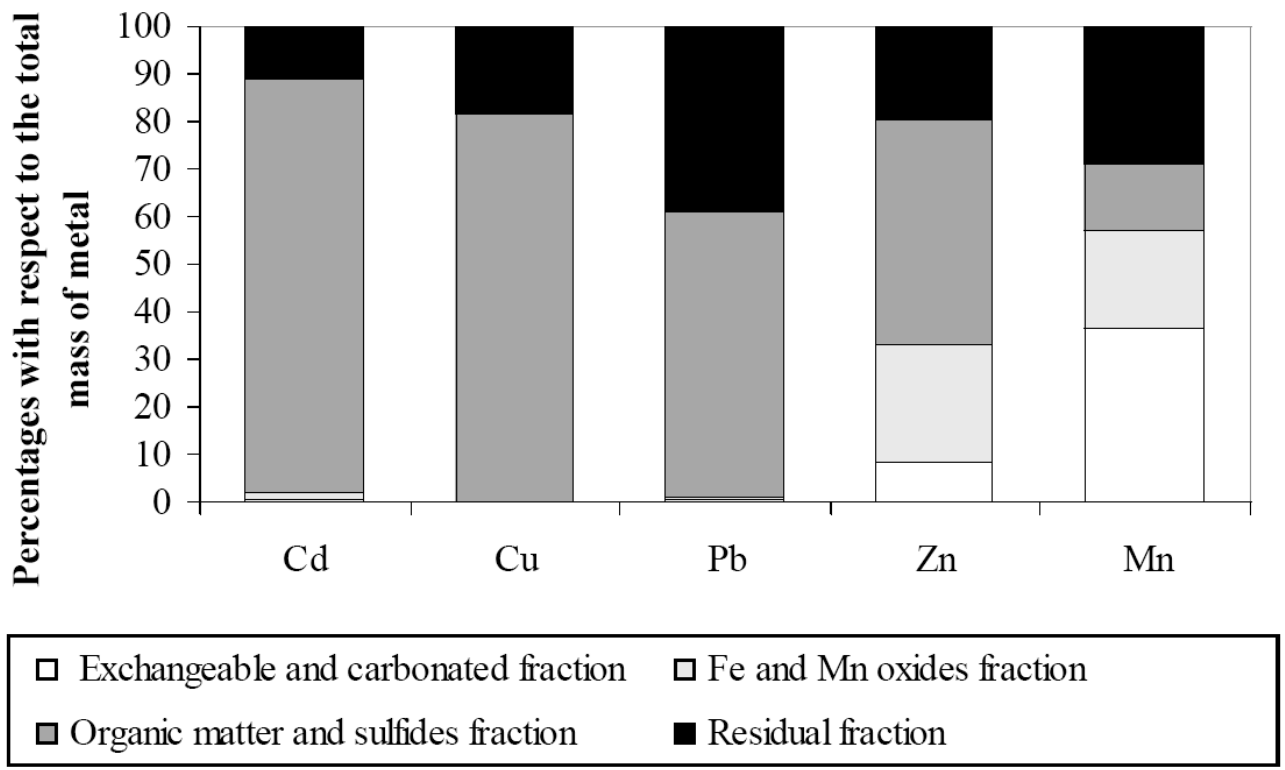

Fig. (3). Heavy metals distribution in the different chemical fractions of the sediments as a percentage of the total mass of each metal.

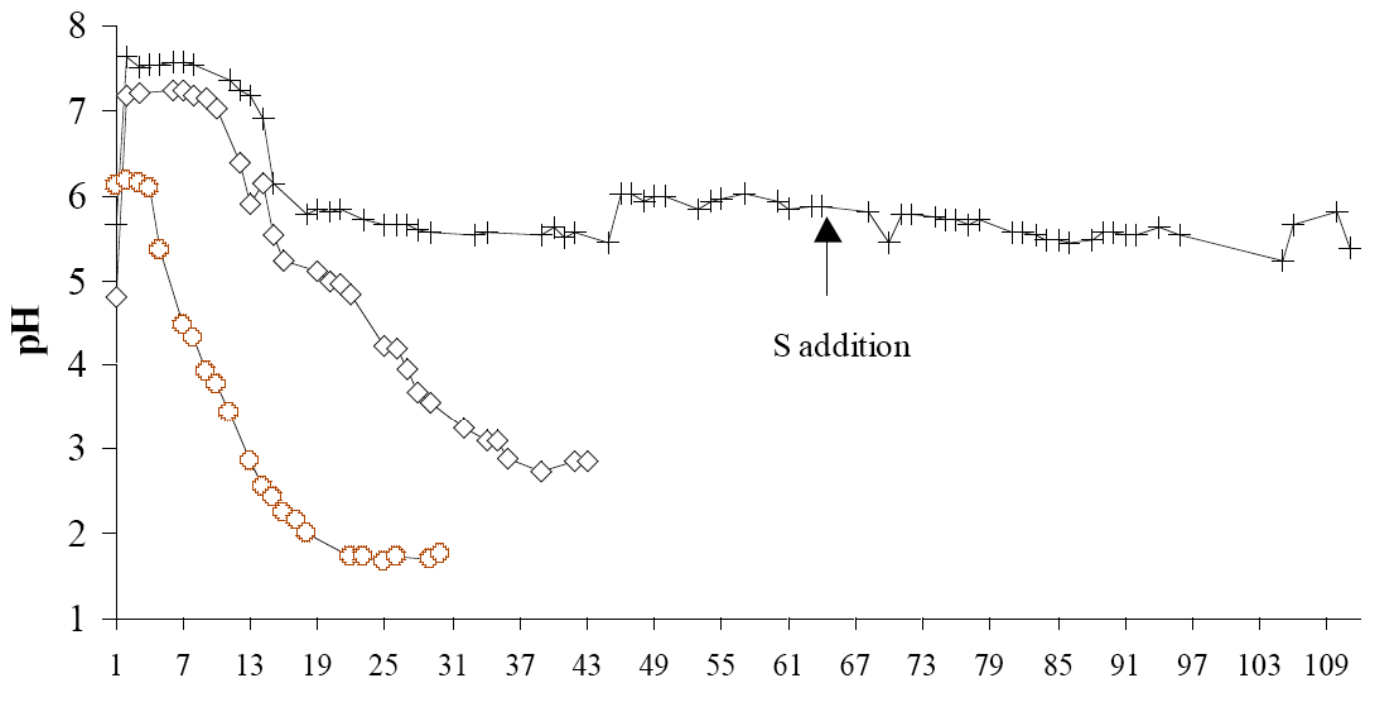

Time in days

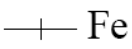

$\prec-\mathrm{Fe} / \mathrm{S}$

$-\mathrm{S}$

Fig. (4). $\mathrm{pH}$ evolution in the $\mathrm{Fe}, \mathrm{Fe} / \mathrm{S}$ and $\mathrm{S}$ treatments.

sediments in the absence of their initial preacidification, and to the slow rate of sulfur oxidization by these bacteria. Also, the extra added sulfur might have become inaccessible to the sulfur oxidizing bacteria naturally present in the sediments due to the deposition of ferric sulfates on it $[34,35]$. The $\mathrm{pH}$ drop was faster in the $\mathrm{Fe} / \mathrm{S}$ treatment. In 43 days, the $\mathrm{pH}$ dropped to about 2.7. The greatest acidification was observed in the $\mathrm{S}$ treatment where the $\mathrm{pH}$ decreased to 1.8 in 30 days. The addition of sulfur to the sediments apparently leads to an important acidification of the sediments, in contrast to the Fe treatment. The improved acidification of the sediments in the $\mathrm{Fe} / \mathrm{S}$ and the $\mathrm{S}$ treatments reflects the activity of neutral sediment oxidizing bacteria in the sediments.

\section{Sulfate Production}

Sulfate production (Fig. 5) seems to be limited in the presence of iron in the sediments. Practically no sulfate was produced in the Fe treatment. With no initial preacidification of the sediments, the operation of lithotrophic bacteria using $\mathrm{Fe}$ as a substrate is limited [32], which explains the limited sulfate production. In the presence of sulfur in the $\mathrm{Fe} / \mathrm{S}$ treatment, a small production $(4.5 \mathrm{~g} / \mathrm{l})$ of sulfate was observed. This production was much more important in the sulfur treatment whereby, at the end of the experiment, around $14 \mathrm{~g} / \mathrm{l}$ of sulfates were produced. This represents around $46 \%$ of the weight of the added sulfur. The suflur concentration is therefore in excess and needs to be lowered 
in the future. This will lower operational costs and prevent the reacidification of sediments after treatment [36]. An increase in sulfate production has also been observed by other researchers $[36,32,4,15,37]$. The acidification of the sediments is thus due to the production of sulfuric acid that results mainly from the oxidation of sulfur into sulfates by the natural lithotrophic bacteria of the sediments.

This conclusion does not however exclude the possibility of the oxidation of sulfur minerals by the microbial population under very acidic conditions [37].

\section{Bioleaching of the Heavy Metals}

The bioleaching of heavy metals from sediments has been expressed, at each sampling day, as a percentage of the total mass of the metal in the sediments. For a given sampling day, the solubilization percentage reflects thus the solubilization that has occurred from the beginning of the experiment to this sampling day. In the Fe treatment (Fig. 6), the $\mathrm{pH}$ did not go below 5.85. Metal solubilization was thus mainly observed for the metals that are linked to the acidsoluble fraction of the sediments, namely $\mathrm{Mn}$ and $\mathrm{Zn}$. Of these two metals, Mn was the most solubilized because it is more mobile than $\mathrm{Zn}$. Cd, linked to the oxidizable fraction, was also solubilized ( $28 \%$ on day 92$)$ inspite of the relatively high $\mathrm{pH}$ value of the sediments. This metal has most probably been solubilized as a result of the abiotic oxidation of cadmium sulfides by the $\mathrm{Fe}^{3+}$ ions present in the medium. The released sulfur would then have been oxidized by the neutral lithotrophic bacteria to form sulfuric acid, leading to the acidification of the sediments and to a corresponding increase in the metal leaching. The slowliness of this chemical reaction explains, in part, the low percentage of cadmium solubilization [35] proposed similar solubilization mechanisms for the solubilization of copper from covellite by Thiobacillus thiooxidans in the presence of iron. No additional $\mathrm{pH}$ lowering or sulfate production and thus no apparent sulfur utilization were noticed after the addition of sulfur to the sediments on day 64 . These phenomena could be explained by a possible inhibition of sediments bacteria by $\mathrm{Fe}^{3+}[35]$ and/or by the inaccessibility of sulfur and metal sulfides to bacteria due the deposition of ferric sulfates on them $[34,35]$. In general, heavy metals solubilization yields are lower than those obtained by [14]. The difference is caused by the lack of the initial acidification of the sediments and probably by a different metal speciation of the heavy metals between the two studies.

Better and faster bioleaching results were obtained in the $\mathrm{Fe} / \mathrm{S}$ treatment in comparison to the Fe treatment (Fig. 7). A similar conclusion has been obtained by [12] who worked on the bioleaching of heavy metals from sewage sludges. On day 42 characterized by a $\mathrm{pH}$ of 2.75 , the significantleaching of $\mathrm{Cd}(83 \%)$ and $\mathrm{Zn}(93 \%)$ and the newly observed leaching of $\mathrm{Cu}(43 \%)$ suggest that leaching occurred, not only from acid soluble (exchangeable and carbonate bound metals) and reducible (metals bound to $\mathrm{Fe}$ and $\mathrm{Mn}$ oxides) sediments fractions, but from the oxidizable ones as well (metals bound to sulfides and the organic matter). This finding, along with the important acidification of the medium, show that heavy metals leaching is essentially biological this time or the result of the activity of the sediments lithotrophic microbial population.

The sulfur treatment (Fig. 8) gave better and faster results than the $\mathrm{Fe} / \mathrm{S}$ treatment. In 30 days, $72 \%$ of $\mathrm{Cu}, 85 \%$ of $\mathrm{Mn}$, $91 \%$ of $\mathrm{Zn}$ and $93 \%$ of $\mathrm{Cd}$ have been solubilized. The significant $\mathrm{pH}$ lowering and sulfate production observed at day $30(14 \mathrm{~g} / \mathrm{l}, \mathrm{pH}: 1.8)$ clearly indicate that the leaching process is tightly related to sulfur oxidation by the sediments lithotrophic bacteria. The results of sulfur treatment are relatively close to those obtained by [4] who operated in airlift bioreactors and higher than those obtained by [38].

In the $\mathrm{Fe} / \mathrm{S}$ and $\mathrm{S}$ treatments, the solubilization of heavy metals can occur through several mechanisms [39, 13, 35]. First, it is thought to be brought about by sediments neutral lithotrophic bacteria which oxidize the added sulfur and

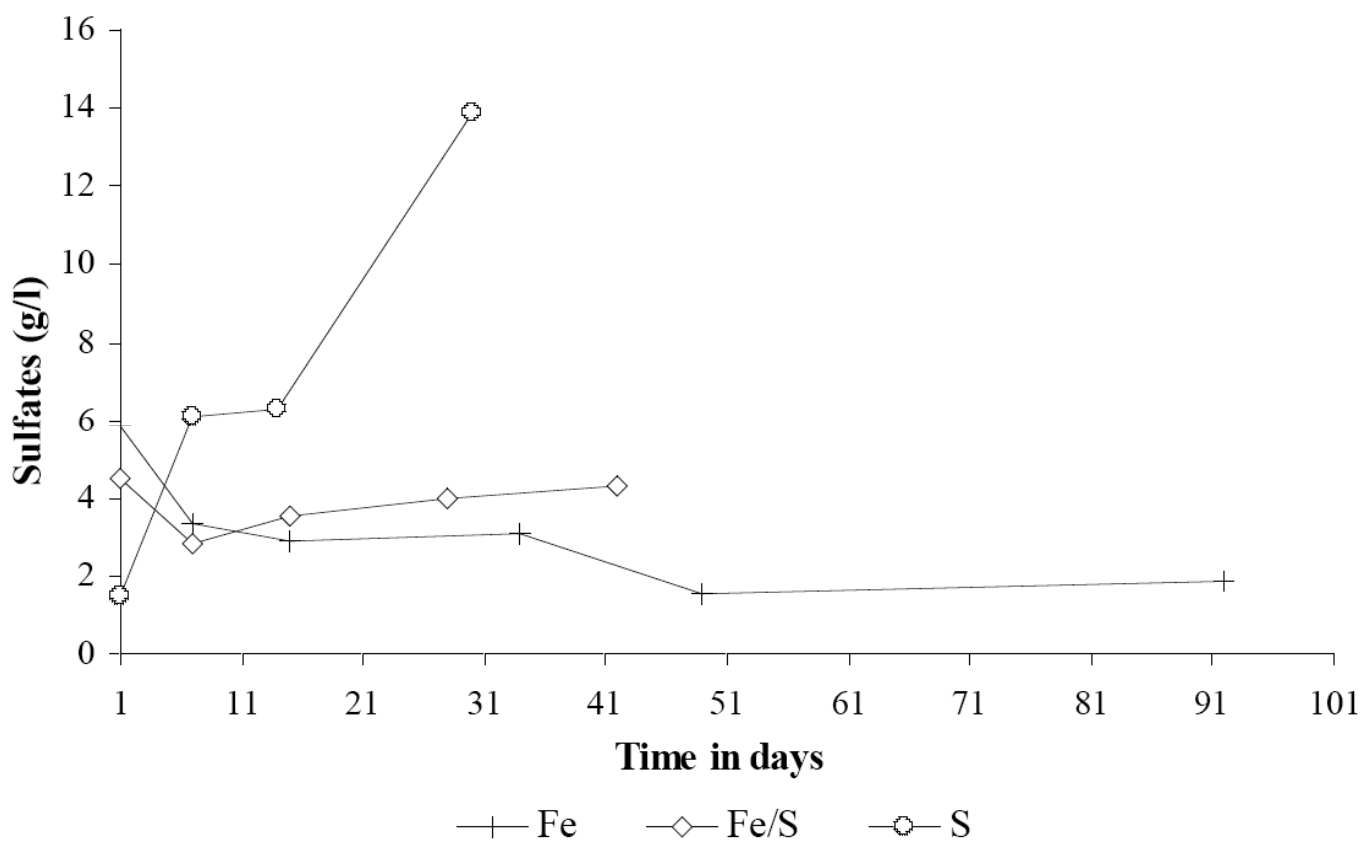

Fig. (5). Evolution of sulfate production in the $\mathrm{Fe}, \mathrm{Fe} / \mathrm{S}$ and $\mathrm{S}$ treatments. 


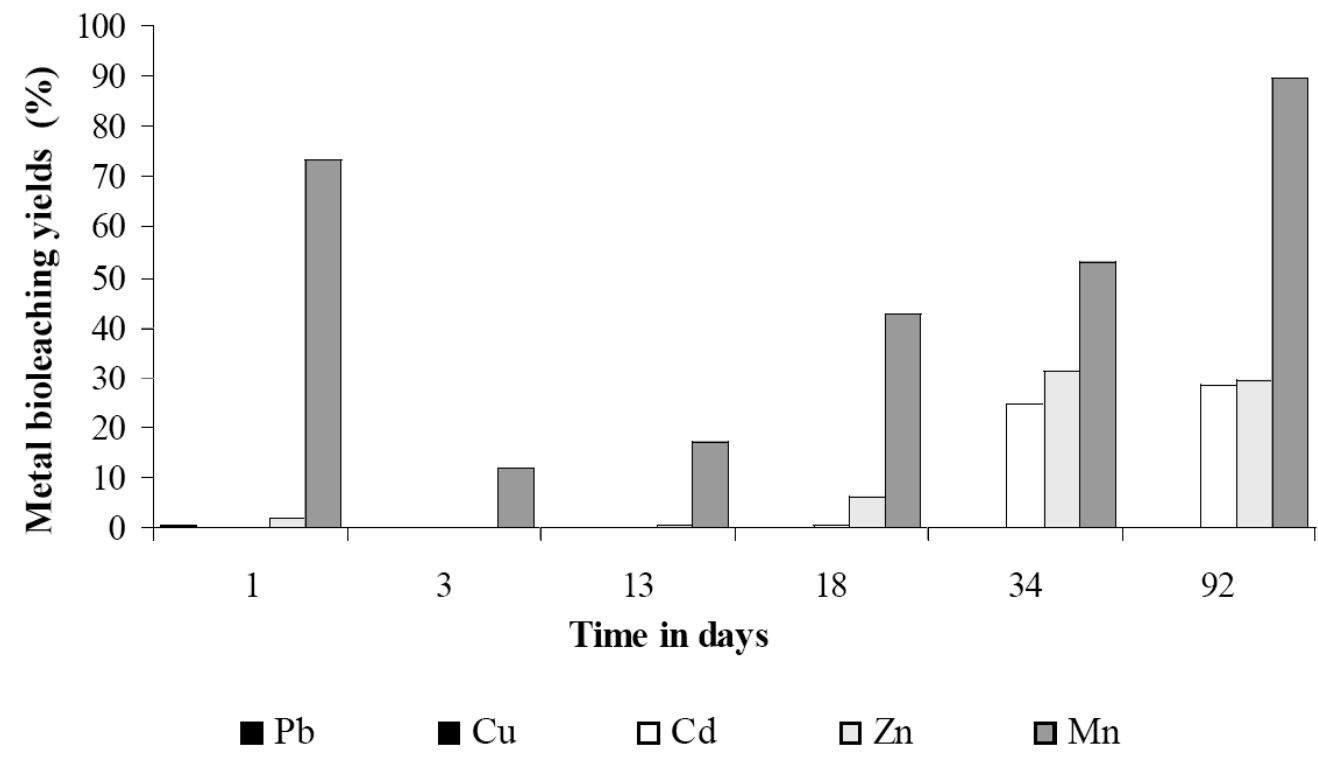

Fig. (6). Bioleaching of heavy metals in the Fe treatment as a percentage, for each metal, of the total sediment metal mass.

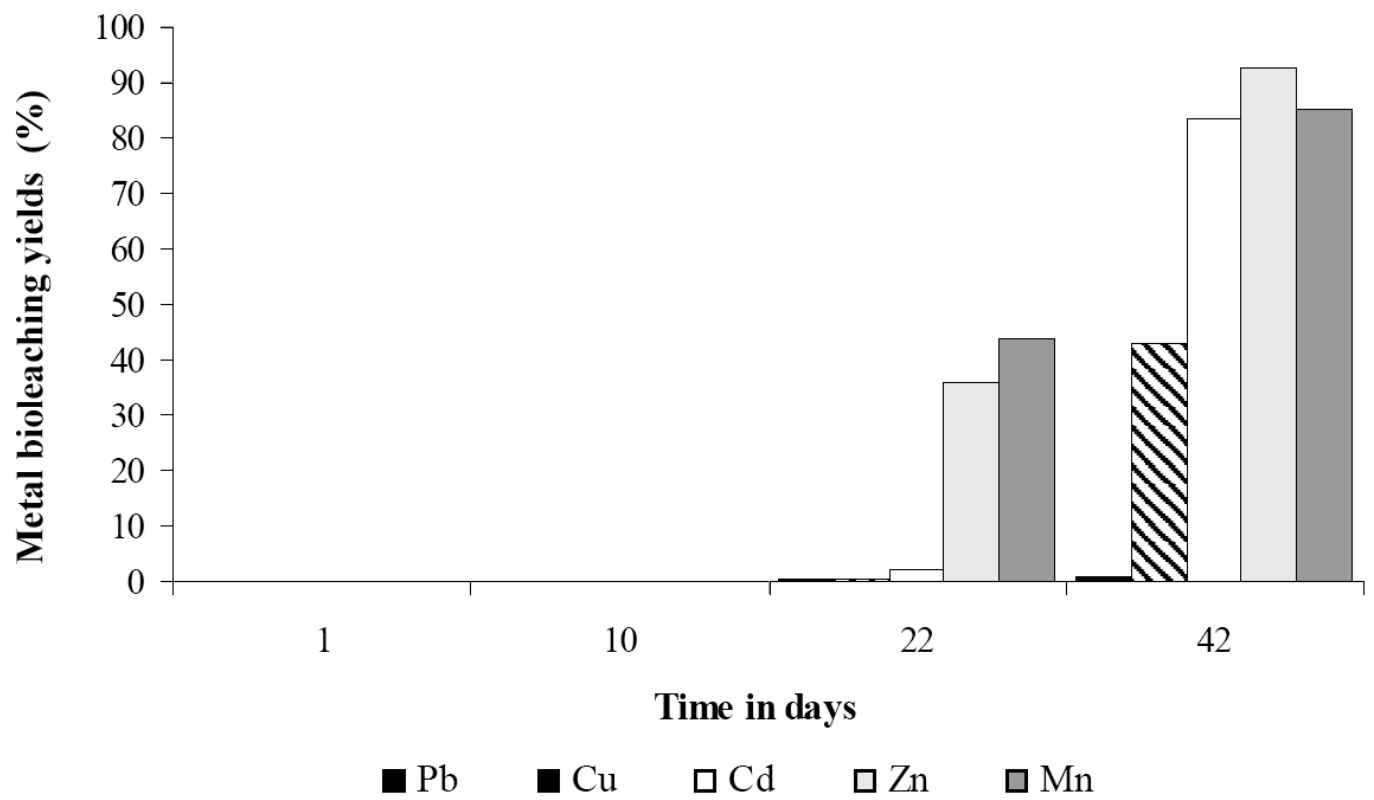

Fig. (7). Bioleaching of heavy metals in the $\mathrm{Fe} / \mathrm{S}$ treatment as a percentage, for each metal, of the total sediment metal mass.

produce sulfuric acid that solubilizes heavy metals. In the $\mathrm{Fe} / \mathrm{S}$ treatment, the presence of the Fe can participate in the bioleaching process through an abiotic oxidation of metal sulfides by the $\mathrm{Fe}^{3+}$ ions. As the $\mathrm{pH}$ decreases, acidophilic lithototrophic bacteria become activated. At very low $\mathrm{pH}$ values, bioleaching can be due, in addition to the above mentioned mechanisms, to the direct oxidation of metal sulfides by some bacteria like Thiobacillus ferrooxidans. The bioleaching of heavy metals can also be indirect. Certain acidophilic bacteria like Thiobacillus thiooxidans are unable to directly oxidize metal sulfides. Instead, they oxidize sulfur or non metallic sulfides $\left(\mathrm{H}_{2} \mathrm{~S}, ..\right)$ to acidify the medium so that $\mathrm{Fe}^{3+}$ ions remain soluble and chemically oxidize metal sulfides. At low $\mathrm{pH}$ values $(\mathrm{pH}<2)$, the indirect bioleaching mechanism can be more important ( 5 to 6 times faster) than the direct mechanism $[40,41]$.
A recapitulation of the highest solubilization percentages reached in the different reatmets is presented in Fig. (9). This figure clearly shows that the $\mathrm{S}$ treatment gave the best bioleaching yields.

Fig. (9) shows also that irrespectively of the nature of the treatment, no significant $\mathrm{Pb}$ solubilization has been achieved. Similar results have been obtained by other researchers [4, $42,15]$ who worked on the bioleaching of heavy metals from contaminated sediments. The low bioleaching yields of lead is explained by the very poor solubility of lead sulfate and represents one of the major handicaps for the bioremediation of sediments by chemolithotrophic bacteria [3, 42, 40]. This handicap can be reduced by supplementing the sediments with chloride ions [43] observed, for an iron based treatment, an increase in the solubilization of lead when the sediments were pre-acidified with $\mathrm{HCl}$ instead of $\mathrm{H}_{2} \mathrm{SO}_{4}$ and supplemented with $\mathrm{FeCl}_{2}$ instead of $\mathrm{FeSO}_{4} \cdot 7 \mathrm{H}_{2} \mathrm{O}$. Not less 


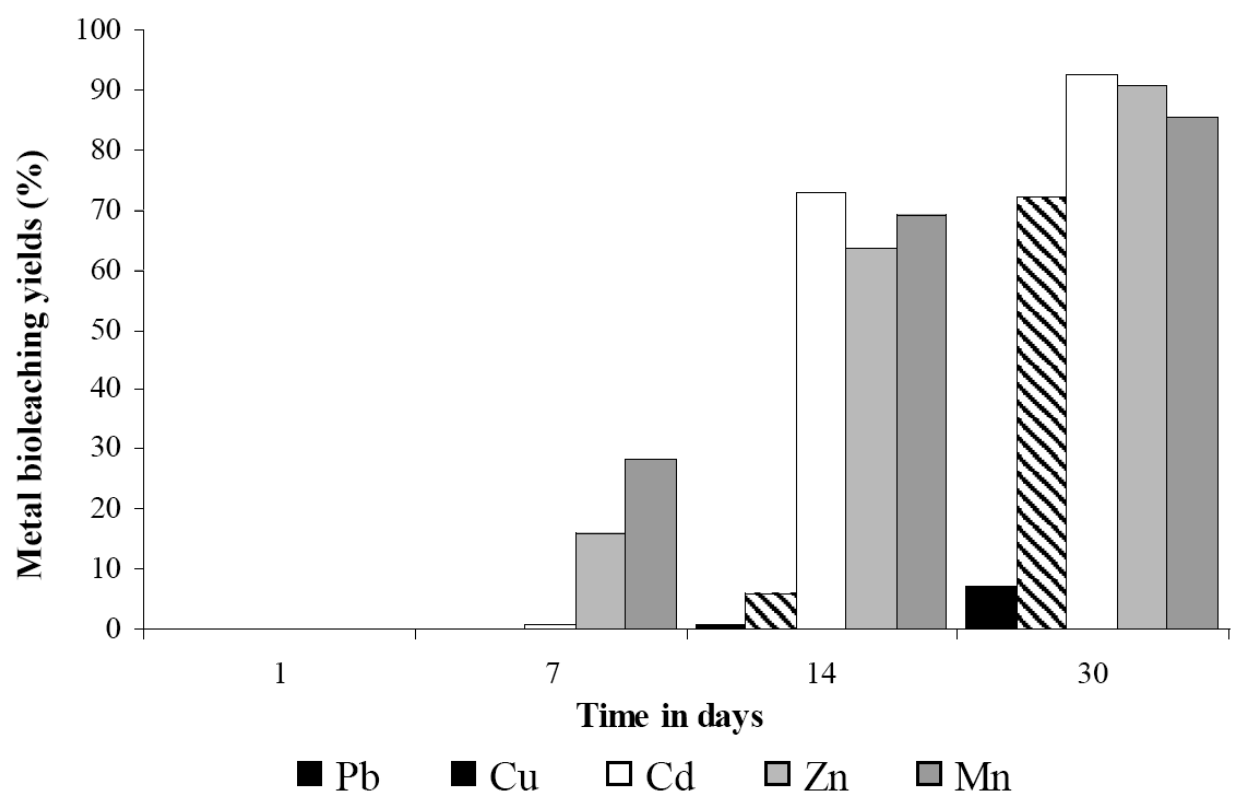

Fig. (8). Bioleaching of heavy metals in the $\mathrm{S}$ treatment as a percentage, for each metal, of the total sediment metal mass.

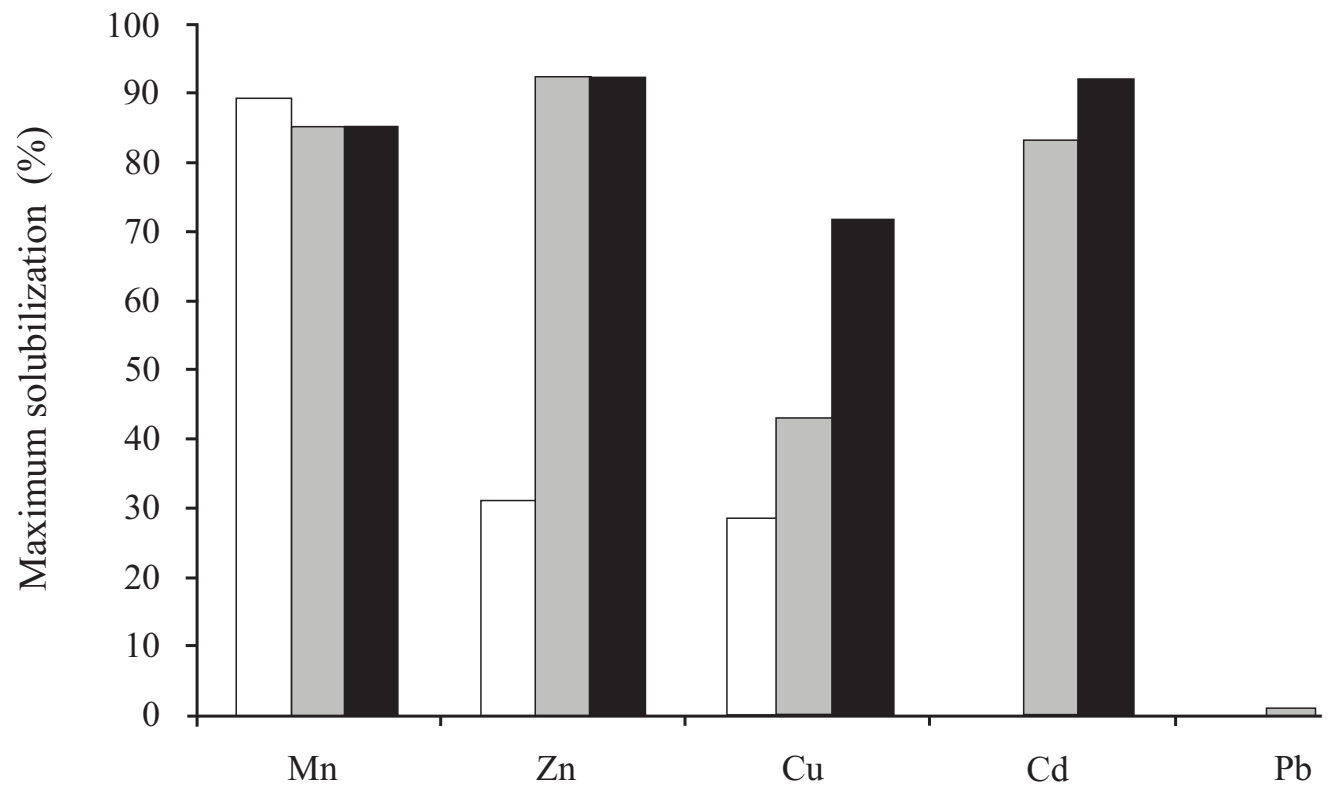

Fig. (9). Maximum solubilization percentages of heavy metals in the different treatments.

than $1500 \mathrm{mg} \mathrm{SO}{ }^{2-} / 1$ should however remain in solution if the activity of the Thiobacilli is to be properly maintained.

\section{Microbiological Studies}

According to Fig. (10), the microbial concentrations on the NT medium are generally higher than those on the GN medium. The supplementation of the sediments with inorganic substrates such as iron and sulfur leads to their enrichment with lithotrophic bacteria. For the $\mathrm{Fe} / \mathrm{S}$ and $\mathrm{S}$ treatments, the microbial concentrations decrease by the end of the treatment. This decrease coincides with the drop in $\mathrm{pH}$ that has been previously observed with the progress of the treatments especially the $\mathrm{Fe} / \mathrm{S}$ and $\mathrm{S}$ treatments. Also, the decrease in microbial counts on the GN medium is a bit higher than that observed on the NT medium. Accordingly, with time, the drop in $\mathrm{pH}$ seems to make the sediments a less favorable medium for the heterotrophic bacteria and the neutral lithotrophic bacteria which grow on the GN and NT media respectively. A decrease in heterotrophic microbial growth with increased medium acidity has been previously reported by [44]. For the $\mathrm{S}$ treatment, few colonies have grown on an acidophilic agar medium (final $\mathrm{pH} 3$ ) enriched with sodium thiosulfate $[22,20]$. However, the identification of these bacteria has been difficult as they barely survived when isolating them for multiplication and identification. For the Fe treatment, no change in microbial concentrations is practically observed between the beginning and the end of the treatment. The metabolic activity of the sediments microbial population is apparently inhibited. This inhibition might be caused by the presence of $\mathrm{Fe}^{3+}$ ions in the sediments [34]. This observation supports the poor acidification of the 


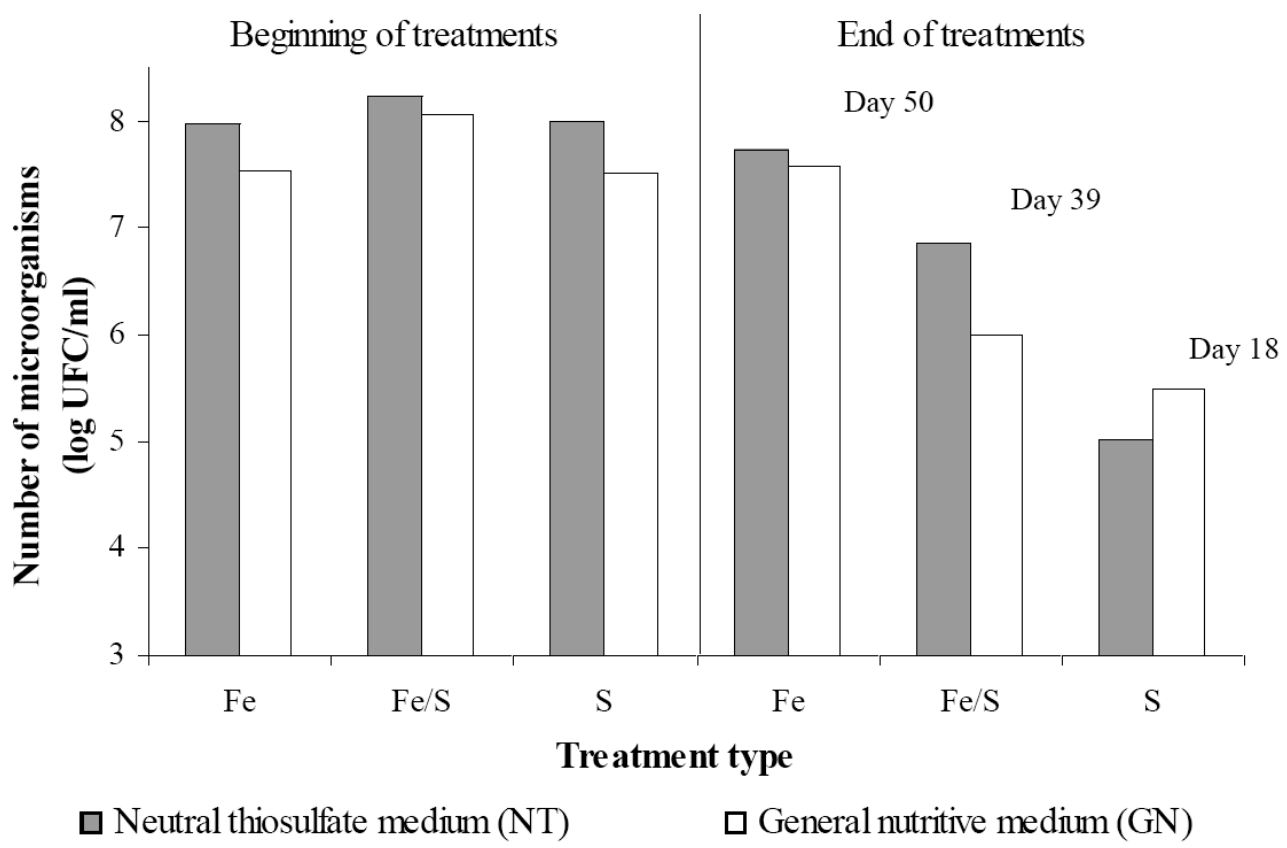

Fig. (10). Variation of the microbiological counts $(\log \mathrm{UFC} / \mathrm{ml})$ between the beginning and the end of Fe, Fe/S and $\mathrm{S}$ treatments.

sediments and the low solubilization yields observed in the Fe treatment.

Physiological tests, described in the materials and methods section, have been conducted on the bacteria that have isolated from the NT medium in order to identify sediments lithotrophic bacteria that were responsible of the $\mathrm{pH}$ drop and the subsequent bioleaching of heavy metals. Given the nature of the tests conducted, only a presumpive identification of the bacterial strains could be achieved. The genera and species are have been potentially identified are presented in Table 3.

Table 3. Presumptive Identification of the Species Isolated from the $\mathrm{Fe}, \mathrm{Fe} / \mathrm{S}$ and $\mathrm{S}$ Treatments

\begin{tabular}{|c|c|}
\hline Treatment & Potentially Identified Species \\
\hline \hline \multirow{3}{*}{$\mathrm{Fe}$} & Thiobacillus tepidarius \\
& Thiobacillus novellus \\
& Thiobacillus versutus \\
& Thiobacillus trautweinii \\
& Thiobacillus sp. \\
\hline & Thiobacillus sp. \\
$\mathrm{Fe} / \mathrm{S}$ & Pseudomonas mesophilica \\
& Pseudomonas paucimobilis \\
& Pseudomonas vesicularis \\
\hline $\mathrm{S}$ & Thiobacillus sp. \\
\hline
\end{tabular}

\section{CONCLUSION}

The present study represents an important challenge in terms of bioremediation as the sediments of concern are highly contaminated wth heavy metals and these were found tightly lnked to the sediments. In the latter concern, the sequential extraction study showed, that with the exception of $\mathrm{Mn}$, the heavy metals were predominantly associated with the oxidizable fraction of the sediments that is to the sulfides and organic matter. Such association is linked not only to the nature of the sediments but to the age of pollution as well. According to the sequential extraction study, the heavy metals could be classified by decreasing order of mobility as follows: $\mathrm{Mn}>\mathrm{Zn}>\mathrm{Cu}>\mathrm{Cd}>>\mathrm{Pb}$.

Successful bioleaching results have been obtained despite the high pollution load and the tight association of the heavy metals to the sediments. The bioleaching experiments showed that the solublization of the heavy metals depended on the nature of the mineral substrate added. Sulfur gave better results than reduced iron or a combination of reduced iron and sulfur. The aerobic lithotrophic bacteria which is naturally present in the sediments oxidized sulfur to produce sulfuric acid. The resulting acidification of the sediments, which caused a decrease in the microbial counts of the heterotrophic and neutral lithotrophic bacteria, led to the release of metals that were tightly bound to the sediments, ie those associated with the sulfides and/or the organic matter. Bioleaching yields expressed as a percentage of the total mass of metal in the sediments varied for the sulfur treatment, over the entire treatment period, between 72 and $93 \%$ for $\mathrm{Mn}, \mathrm{Cu}, \mathrm{Cd}$ and $\mathrm{Zn}$. The sulfur treatment has all the potential to be applied at a larger scale after some optimization work like the need to reduce the concentration of the sulfur substrate which was found in excess in the study.

Practically, no $\mathrm{Pb}$ was solubilized because of the low solubility of lead sulfate. The present work shows that lithotrophic bacterial leaching is of limited efficacy for bioleaching $\mathrm{Pb}$ from sediments. More research work including the use of $\mathrm{FeCl}_{2}$ as a substrate would be needed to improve the results. In parellel, the low mobility of $\mathrm{Pb}$ is a point to be taken into consideration when setting the cleanup end points for the studied sediments.

The present study showed that it is possible to achieve a bioleaching of heavy metals without an initial acidification 
of the sediments when using sulfur or a combination of $\mathrm{Fe}$ and sulfur. Besides lowering treatment costs, this avoids foaming or the evolution of $\mathrm{CO}_{2}$ and the toxic $\mathrm{H}_{2} \mathrm{~S}$.gas from the sediments during the treatment.

\section{ACKNOWLEDGEMENTS}

Thanks are expressed to the Agence de l'Eau ArtoisPicardie, the Conseil Régional Nord-Pas de Calais and the Direction Régionale pour l'Environnement in France for their financial support of this study. Thanks are also expressed to the laboratories CREID and AGREN for conducting the heavy metals and sulfates analyses.

\section{CONFLICT OF INTEREST}

None declared.

\section{REFERENCES}

[1] Regional Direction of the Environment, Installation and Lodging, Position of the North Not of Wedged, DRIRE North - Pas-deCalais - IRE 2007 - GROUNDS. 352, 2007, http://www.nord-pasde-calais.developpement-durable.gouv.fr

[2] Ministry of the Ecologie and sustainable Development/ministry of the Installation of the Territory and Environment/Agencies of the Water/Royal Haskoning, Etudes on the water in France, Report No. 89, National Historic Operations of Cleaning out and Perspectives, synthesis report, 2002

[3] Rulkens W. Introduction to the treatment of polluted sediments. Rev Environ Sci Biotechnol 2005; 4: 21-221

[4] Chen SY, Lin JG. Bioleaching of heavy metals from contaminated sediment by indigenous sulfur-oxidizing bacteria in air-lift bioreactor: effect of sulfur concentration. Water Res 2004; 38 : 3205-14.

[5] Tabak HH, Lens P, Van Hullebusch ED, Dejonghe W. Developments in bioremediation of soils and sediments polluted with metals and radionuclides-1. Microbial processes and mechanisms affecting bioremediation of metal contamination and influencing metal toxicity and transport. Rev Environ Sci Biotechnol 2005; 4: 115-6.

[6] Johnson DB. Acidophilic microbial communities: candidates for bioremediation of acidic mine efffluents. Int Biodeter Biodegr 1995; 41-58.

[7] Bosecker K. Bioleaching: metal solubilization by microoganisms. FEMS Microbiol Rev 1997; 20: 591-604.

[8] Krebs W, Brombacher C, Bosshard PP, Bachofen R, Brandl H. Microbial recovery of metals from solids. FEMS Microbiol Rev 1997; 20: 605-17.

[9] Couillard D, Chartier M. Removal of metals from aerobic sludges by biological solubilization in batch reactors. J Biotechnol 1991; 20: $163-80$.

[10] Guay R, Silver M, Torma AE. Microbiological leaching of lowgrade uranium ore by Thiobacillus ferrooxidans. Eur J Appl Microbiol 1976; 3: 157-67

[11] Lundgren DG, Silver M. Ore leaching by bacteria. Ann Rev Microbiol 1982; 34: 263-83

[12] Tyagi RD, Couillard D, Tran F. Heavy metals removal from anaerobically digested sludge by chemical and microbiological methods. Environ Pollut 1988; 50: 295-316.

[13] Blais JF, Tyagi RD, Auclair JC. Bioleaching of metals from sewage sludge: microorganisms and growth kinetics. Water Res 1993; 27 (1): 101-10.

[14] Couillard D, Chartier M, Mercier G. Etude de l'enlèvement du Cd, $\mathrm{Cu}, \mathrm{Mn}$ et $\mathrm{Zn}$ par solubilisation biologique dans les sédiments lacustres contaminés. Revue Sci L'Eau 1994; 7: 251-68.

[15] Seidel H, Ondruschka J, Morgenstern P, Stottmeister U. Bioleaching of heavy metals from contaminated aquatic sediments using indigenous sulfur-oxidizing bacteria: a feasibility study. Water Sci Tech 1998; 37 (6-7): 387-94.

[16] Quevauviller P, Rauret G, Muntau H, et al. Evaluation of sequential extraction procedure for the determination of extractable metal contents in sediments. Fresen J Anal Chem 1994; 349: 80814.
[17] U.S. Environmental Protection Agency, EPA method 3051: microwave acid assisted digestion of sediments, sludges, soils and oils, 2003, Web site: www.epa.gov/epaoswer:hazwaste/test/3_series.htm

[18] Coetzee PP, Gouws K, Plüddemann S, Yacoby M, Howell S, Drijver L den. Evaluation of sequential extraction procedures for metal speciation in model sediments. Water SA 1995; 21 (1): 5160 .

[19] Laishley EJ, Rae K, Dillman AM, Bryant RD. Characterization of a new acidophilic Thiobacillus isolate (Thiobacillus capsulatus). Can J Microbiol 1988; 34: 960-6.

[20] Reynolds DM, Laishley EJ, Costerton JW. Physiological and ultrastructural characterization of a new acidophilic Thiobacillus species (T. kakobis). Can J Microbiol 1981; 59: 151-61.

[21] Blais JF, Auclair JC, Tyagi RD. Cooperation between two Thiobacillus strains for heavy-metal removal from municipal sludge. Can J Microbiol 1992; 38: 181-7.

[22] Barton LL, Shively JM. Thiosulfate utilization by Thiobacillus thiooxodans ATCC 8085. J Bacteriol 1968; 95 (2): 720.

[23] French Agency of Normalization. Anthology of French Norms Environments. Quality of water, Methods of Analysis 2, 2nd ed. Major elements, other elements and composed minerals. AFNOR Publishers : Paris 1997; p. 329.

[24] Group of Operational Work of the Thematic Toxic sediments of the Center of Competence on the Sites and Polluted Grounds, NorthNo Wedged 1998. Abduction of the toxic sediments, guide méthodologique. Is it necessary to clean? For an assistance to the taken decision. North not of Calais, France. http://intraged:8080/etude/basedoc/sediments/guide_methodologiq ue/pre000.htm 05/10/2004

[25] Bodog I, Polyak K, Hlavay J. Determination of heavy metals in lake and river sediments by selective leaching. Int J Environ Analyt Chem 1997; 66: 79-94.

[26] Hlavay J, Polyak K. Chemical speciation of elements in sediment samples collected at lake Balaton. Microchem J 1998; 58: 281-90.

[27] Yu KC, Tsailj, Chen SH, and Ho ST. Chemical binding of heavy metals in anoxic river sediments. Water Res 2001; 35 (17): 408694.

[28] Yu KC, Tsailj, Chen SH. and Ho ST. Correlation analyses on binding behavior of heavy metals with sediment matrices. Water Res 2001; 35 (10): 2417-28.

[29] Tsailj, Yu KC, Chen SF, Kung PY, Chang CY, Lin CH. Partinioning variation of heavy metals in contaminated river sediment via bioleaching: effect of sulfur added to total solids ratio. Water Res 2003; 37: 4623-30.

[30] Usero J, Gamero M, Morillo J and Gracia I. Comparative study of three sequential extraction procedures for metals in marine sediments. Environ Int 1998; 24 (4): 487-96.

[31] Mester Z, Cremisini C, Ghiara E, Morabito R. Comparison of two sequential extraction procedures for metal fractionation in sediment samples. Anal Chim Acta 1998; 359: 133-42.

[32] Chen SY, Lin JG. Bioleaching of heavy metals from sediment: significance of $\mathrm{pH}$. Chemosphere 2001; 44: 1093-102.

[33] Wong LTK, Henry JG. Bacterial leaching of heavy metals from anaerobically digested sludge. In: Wise DL (ed), Biotreatment Systems. CRC Press: Boca Raton, FL 1988; pp.125-69.

[34] Curutchet G, Pogliani C, Donati E, Tedesco P. Effect of iron(III) and its hydrolysis products (jarosites) on Thiobacillus ferrooxidans growth and on bacteria leaching. Biotechnol Lett 1992; 14: 329-34.

[35] Donati E, Curutchet G, Pogliani C, Tedesco P. Bioleaching of covellite using pure and mixed cultures of Thiobacillus ferrooxidans and Thiobacillus thiooxidans. Process Biochem 1996; 31 (2): 129-34.

[36] Fang D. Effects of sulfur forms on heavy metals bioleaching from contaminated sediments, J Environ Sci Health A Toxic Hazard Subst Environ Eng 2009; 44 (7): 714-21.

[37] Tyagi RD, Blais JF, Auclair JC, Meunier N. Bacterial leaching of toxic metals from municipal sludge: influence of sludge characteristics. Water Environ Res 1993; 65 (3): 196-204.

[38] Fang D, Zhao L, Yang ZQ, Shan HX, Gao Y and Yang Q. Effect of sulphur concentration on bioleaching of heavy metals from contaminated dredged sediments. Environ Technol 2009; 30 (12): 1241-8.

[39] Bosecker K. Bioleaching of valuable metals from silicate ores and silicate waste products. In: Biohydrometallurgy-Proceedings of the International Symposium, Jackson Hale, W.P. 1989. 
[40] Tichy R, Lens P, Grotenhuis JTC, Bos P. Solid-state reduced sulfur compounds : environmental aspects and bioremediation. Crit Rev Environ Sci Technol 1998; 28 (1): 1-40.

[41] Donati ER, Porro S, Tedesco PH. Direct and indirect mechanisms in the bacterial leaching of covellite. Biotechnol Lett 1988; 10: $889-94$.

[42] Nareshkumar R, Nagendran R, Parvathi K. Bioleaching of heavy metals from contaminated soil using Acidithiobacillus thiooxidans: effect of sulfur/soil ratio. World J Microbiol Biotechnol 2008; 24: 1539-46.

[43] Mercier G, Chartier M, Couillard D. Strategies to maximize the microbial leaching of lead from metal contaminated aquatic sediments. Water Res 1996; 10: 2452-64.

[44] Baker MD, Innis WE, Mayfield CI, Wong PTS. Effect of pH on the growth and activity of heterotrophic sediment microorganisms. Chemosphere 1982; 11 (10): 973-83.

(C) Sabra et al.; Licensee Bentham Open .

This is an open access article licensed under the terms of the Creative Commons Attribution Non-Commercial License (http://creativecommons.org/licenses/by$\mathrm{nc} / 3.0 /$ ) which permits unrestricted, non-commercial use, distribution and reproduction in any medium, provided the work is properly cited. 